\title{
15. NANNOFOSSIL BIOSTRATIGRAPHY FOR ANTARCTIC SEDIMENTS, LEG 28, DEEP SEA DRILLING PROJECT
}

\author{
D.A. Burns, New Zealand Oceanographic Institute, Department of Scientific \\ and Industrial Research, Wellington, New Zealand
}

\section{INTRODUCTION}

Leg 28 (DSDP) was the first attempt to drill into the deeper layers of sediment beneath the Southeast Indian Ocean and waters around Antarctica. Inasmuch as the nannofossil zonal schemes presently in use are based to a large degree on warm-water sequences, the distribution of nannofossils at the high latitudes of Leg 28 has been unknown. The nannofossil assemblages recovered from Leg 28 are dealt with in detail below. Each site is considered separately and the basis for biostratigraphic age assignment is discussed. It should be noted that the zonal numbers suggested by Martini and Worsley (1970) are not used, although in some cases a zone fossil is present in the sediment. Such omission is a means of stressing that the sporadic occurrence of one or two specimens of a zone fossil is not taken as an indication that the enclosing sediment is equivalent to the complete zone of Martini and Worsley. Similarly, the absolute age limits for such a zone cannot necessarily be applied to the present sections.

\section{SITE 265}

Site 265 is situated on the southern flank of the Southeast Indian Ridge. The sediments cored range from Recent to middle Miocene and can be divided into two distinct units: (1) an upper unit of sediments formed predominantly of siliceous microfossils, but which contain occasional specimens of nannofossils or layers of nannofossil-bearing sediments; (2) a lower unit of sediments formed predominantly of nannofossils.

\section{Upper Unit}

In the upper, siliceous sediments (Sample 1-1, $50 \mathrm{~cm}$ to Sample 14-6-125 cm) it is difficult to position stratigraphic boundaries based on nannofossils because of their sporadic distribution.

In this upper section, the nannofossils, when present, are predominantly placoliths consisting of species such as Emiliana huxleyi, Gephyrocapsa oceanica, Pseudoemiliania lacunosa, Cyclococcolithus leptoporus, Helicopontosphaera kamptneri, Coccolithus pelagicus, a small Gephyrocapsa species, Umbilicosphaera mirabilis, Gephyrocapsa caribbeanica, Reticulofenestra pseudoumbilica, Cyclococcolithina macintyeri. Abundance generally varies from barren or very rare (three specimens per slide) to few, and preservation from poor to moderate. Detailed distribution of species is shown in Table 1.

\section{Quaternary}

Sample 1-1, $50 \mathrm{~cm}$ to Sample 2-6, $100 \mathrm{~cm}$; E. huxleyi; Pleistocene.
TABLE 1A

Distribution of Nannofossils at Site $\mathbf{2 6 5}$

\begin{tabular}{|c|c|c|c|c|c|c|c|}
\hline $\begin{array}{c}\text { Sample } \\
\text { (Interval } \\
\text { in } \mathrm{cm} \text { ) }\end{array}$ & 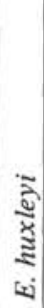 & 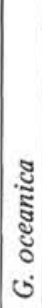 & 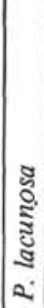 & 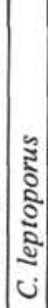 & 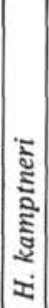 & 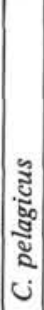 & 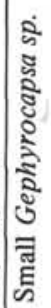 \\
\hline $1-1,50$ & + & + & & + & + & & \\
\hline $\begin{array}{c}1-2,70 \\
\text { to } \\
2-5,66\end{array}$ & \multicolumn{7}{|c|}{ Barren } \\
\hline $2-6,75$ & + & + & & + & + & + & \\
\hline $2-6,100$ & + & + & & + & + & + & \\
\hline $\begin{array}{c}3-1,100 \\
\text { to } \\
3-3,60\end{array}$ & \multicolumn{7}{|c|}{ Barren } \\
\hline $3-4,110$ & & $\mathrm{vr}$ & & & & & \\
\hline $4-1,27$ & & & & + & & & $A$ \\
\hline $4-2,60$ & \multicolumn{7}{|c|}{ Barren } \\
\hline $4-3,60$ & & & & & & & $\mathrm{vr}$ \\
\hline $5-1,20$ & & + & + & + & & + & + \\
\hline $5-1,63$ & & + & + & + & & + & \\
\hline $5-2,60$ & \multicolumn{7}{|c|}{ Barren } \\
\hline $5-3,60$ & & + & + & & & & \\
\hline $5-4,109$ & & + & + & + & + & & \\
\hline $5-5,60$ & & + & + & + & + & + & \\
\hline $\begin{array}{c}5-6,60 \\
\text { to } \\
6-4,56\end{array}$ & \multicolumn{7}{|c|}{ Barren } \\
\hline $7-1,40$ & & + & + & + & & + & \\
\hline $7-2,60$ & & + & & & & + & \\
\hline $7-2,118$ & \multicolumn{7}{|c|}{ Barren } \\
\hline $7-3,60$ & \multicolumn{7}{|c|}{ Barren } \\
\hline $7-4,60$ & & + & + & + & + & + & \\
\hline $7-5,56$ & & + & + & + & + & + & \\
\hline $7-6,60$ & & + & + & + & + & + & \\
\hline $8-2,60$ & & + & + & + & + & + & \\
\hline $8-3,60$ & & + & + & + & + & + & \\
\hline
\end{tabular}

Note: $+=$ Specimens of the species commonly present, but relative numbers not assessed; $\mathrm{A}=\mathrm{Abun}-$ dant; $B=B$ ase plate only present; $\mathrm{R}=$ Rare; $\mathrm{F}=\mathrm{F}$ requent; $\mathrm{S}=\mathrm{Several}$; $\mathrm{X}=\mathrm{One}$ specimen only; $\mathrm{C}=\mathrm{Com}-$ mon; VR=Very rare (2-3 specimens only in a complete traverse of the slide).

Sample $3-4,110 \mathrm{~cm}$ to Sample 4-3, $60 \mathrm{~cm}$; Gephyrocapsa sp.; Pleistocene.

Sample 5-1, $20 \mathrm{~cm}$ to Sample 9-4, $60 \mathrm{~cm}$; P. lacunosa; Pleistocene. 


\section{Pliocene/Pleistocene Boundary}

It is impossible to locate or accurately position the Pliocene/Pleistocene boundary on the basis of nannofossils at this site. Siliceous microfossil stratigraphy indicates that the boundary is contained within the interval between Sample 9-5, $55 \mathrm{~cm}$ and Sample 10-1, 60 $\mathrm{cm}$. This interval is barren of nannofossils (Table 1B). Only the sediments above (Sample 9-4, $60 \mathrm{~cm}$ ) and below $(10-2,60 \mathrm{~cm})$ contain nannofossil specimens. However, even in these nannofossil-bearing sediments, the absence of Discoaster makes positioning of the Plio/Pleistocene boundary impossible. Hence, detailed age assignment for the interval from $9-1,60 \mathrm{~cm}$ to $13-1$, $0 \mathrm{~cm}$ is difficult. The only age indication given for this interval by the nannofossils is the first occurrence of the lower Pleistocene zone fossil Pseudoemiliania lacunosa. However, as the lower range of this species is usually well into the Pliocene, this first occurrence of $P$. lacunosa may only be taken as having a limited stratigraphical significance and suggests that the sediments below this point may be of late Pliocene age or older.

\section{Pliocene}

Sample 10-2, $60 \mathrm{~cm}$ to Sample 13-1, $0 \mathrm{~cm}$; discoasters absent, $P$. lacunosa present; upper Pliocene or older.

Sample $13-1,0 \mathrm{~cm} ; R$. pseudoumbilica, discoasters absent; lower Pliocene.

Sample 13-2, $139 \mathrm{~cm} ; R$. pseudoumbilica, Discoaster asymmetricus, D. brouweri; lower Pliocene.

TABLE 1B

Distribution of Nannofossils at Site 265

\begin{tabular}{|c|c|c|c|c|c|c|c|c|c|c|c|c|c|c|c|c|c|c|}
\hline $\begin{array}{c}\text { Sample } \\
\text { (Interval } \\
\text { in } \mathrm{cm} \text { ) }\end{array}$ & 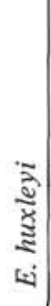 & 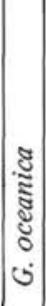 & 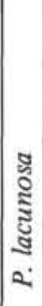 & 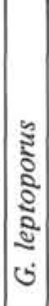 & 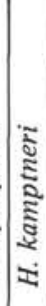 & 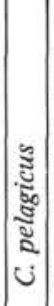 & 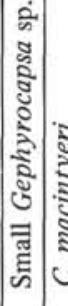 & 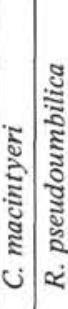 & 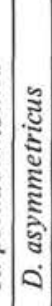 & 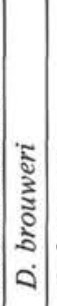 & $\mid$ & 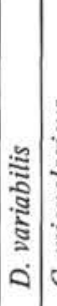 & 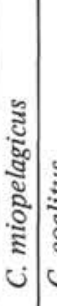 & : & 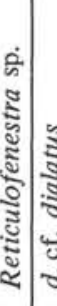 & 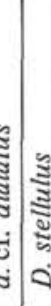 & 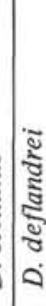 & 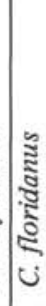 \\
\hline $8-4,60$ & & + & & + & & + & & & & & & & & & & & & \\
\hline $8-5,80$ & & & & & & & & & & arren & & & & & & & & \\
\hline $9-1,60$ & & + & + & & + & + & & & & & & & & & & & & \\
\hline $9-2,60$ & & + & & & & & & & & & & & & & & & & \\
\hline $9-3,60$ & & + & + & & & $t$ & & & & & & & & & & & & \\
\hline $9-4,60$ & & + & + & & & + & & & & & & & & & & & & \\
\hline $\begin{array}{c}9-5,55 \\
\text { to } \\
10-1,60\end{array}$ & & & & & & & & & & arren & & & & & & & & \\
\hline $10-2,60$ & & + & & & & + & & & & & & & & & & & & \\
\hline $10-3,60$ & & + & & & & & & & & & & & & & & & & \\
\hline $10-4,60$ & & + & & + & & + & & & & & & & & & & & & \\
\hline $10-5,60$ & & & & & & & & & & arren & & & & & & & & \\
\hline $\begin{array}{c}\text { Core } 11 \\
\text { to } \\
\text { Core } 12\end{array}$ & & & & & & & & & & arren & & & & & & & & \\
\hline $13-1,130$ & & & & + & & + & & & & & & & & & & & & \\
\hline $13-2,139$ & & & & + & & + & & $+\quad+$ & & & & & & & & & & \\
\hline $13-3,143$ & & & & + & & + & & ++ & + & + & & & & & & & & \\
\hline $\begin{array}{c}14-1,75 \\
\text { to } \\
14-5,125\end{array}$ & & & & & & & & & & arren & & & & & & & & \\
\hline $14-6,125$ & & & & + & & + & & + & & & & & & & & & & \\
\hline $15-1,46$ & & & & + & & + & & $\begin{array}{lll}+ & & \end{array}$ & & & + & & & t & + & + & & \\
\hline $15-2,30$ & & & & + & & $\begin{array}{llll}+ & & & \\
\end{array}$ & & + & & & + & & & & + & & + & \\
\hline $15-3,122$ & & & & + & & + & & + & & & + & 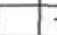 & + & + & + & $\begin{array}{l}+ \\
+\end{array}$ & & \\
\hline $15-4,110$ & & & & + & & + & & + & & & + & + & & & + & + & + & \\
\hline $15-5,112$ & & & & & & & & + & & & & + & + & + & & & & \\
\hline $15-6,33$ & & & & & & + & & $\begin{array}{lll}+ \\
+\end{array}$ & & & & + & & + & + & & $\begin{array}{llll}+ & & & \\
\end{array}$ & \\
\hline $15-6,113$ & & & & & & + & & + & & & & 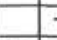 & + & + & $+\quad+$ & & & \\
\hline $16-1,36$ & & & & & & + & & + & & & & + & & + & \begin{tabular}{l|l}
+ \\
\end{tabular} & & + & \\
\hline $16-2,16$ & & & & & & + & & + & & & & + & & + & + & & & \\
\hline $16-3,29$ & & & & & & + & & + & & & & + & & \pm & + & & & \\
\hline $16-4,69$ & & & & & & + & & $\begin{array}{lll}+ & \\
\end{array}$ & & & & & & & + & & & \\
\hline $16-5,35$ & & & & & & + & & + & & & & & & + & + & & + & + \\
\hline $16-6,115$ & & & & & & + & & + & & & & + & & & + & & + & + \\
\hline
\end{tabular}

Note: See Table 1A for explanation of symbols. 
Sample 14-1, $75 \mathrm{~cm}$ to Sample 14-6, $125 \mathrm{~cm} ; R$. pseudoumbilica, $C$. macintyeri; lower Pliocene of unknown pecific age.

The Pliocene is extremely difficult to recognize because of the general absence of Discoasters. The presence of Reticulofenestra pseudoumbilica in Sample $13-1,0 \mathrm{~cm}$ certainly indicates that this sediment and those below are at least of Pliocene age. However, in the absence of $D$. brouweri, D. surculus, or D. pentaradiatus above this horizon, it is impossible to know which part of the Pliocene this sediment represents. It would be erroneous to equate it directly with the $R$. pseudoumbilica lower Pliocene zone (NN15) of Martini and Worsley (1970) as there is no clear indication as to the top of the zone. However, the presence in the section of $D$. asymmetricus along with $D$. brouweri suggests that some part of this sequence (Cores 12 and 13) corresponds to the lower Pliocene age equivalent to the NN15 Zone of Martini and Worsley. The presence of $D$. asymmetricus in Sample 13-2, $139 \mathrm{~cm}$ also suggests that these sediments are of lower Pliocene age.

\section{Miocene/Pliocene Boundary}

Siliceous microfossil stratigraphy indicates that the Miocene/Pliocene boundary at Site 265 is located between the middle of Core 14 and the top of Core 15. Accurate selection of the position of this boundary is impossible using nannofossil stratigraphy as the sediments at the base of Core 14 are either barren (Sample $14-1,75 \mathrm{~cm}$ to Sample $14-5,125 \mathrm{~cm}$ ) or contain only general, lower Pliocene/upper Miocene, background placoliths (C. pelagicus, $R$. pseudoumbilica in Sample 14$6,75 \mathrm{~cm})$. The Ceratoliths diagnostic of the boundary are absent. The uppermost sediments of Core 15 (15-1, $46 \mathrm{~cm}$ ) are definitely of upper Miocene age. Consequently, the Miocene/Pliocene boundary is either in the lowest section of Core 14 or in the interval not sampled between Cores 14 and 15 .

\section{Lower Unit}

Cores 15 and 16 contain the second type of sediment which is predominantly formed of nannofossils and calcareous material, but which still contain some siliceous microfossils. The nannofossil assemblages of this section are again dominated by placoliths, but several Discoaster specimens can be found in the assemblages. This section of sediments affords good nannofossil stratigraphic control and contains the upper/middle Miocene boundary.

The sediments can be stratigraphically subdivided as follows:

Sample 15-1, $46 \mathrm{~cm}$; Discoaster quinqueramus; upper Miocene.

Sample 15-2, $30 \mathrm{~cm}$ to Sample 15-4, $110 \mathrm{~cm} ; D$. hamatus; middle Miocene.

Sample 15-5, $112 \mathrm{~cm}$ to Sample 16-1, $37 \mathrm{~cm}$; Catinaster coalitus; middle Miocene.

Sample 16-2, $16 \mathrm{~cm}$ to Sample 16-6, $115 \mathrm{~cm}$; D. deflandrei; middle Miocene.

The presence of specimens of D. hamatus, $C$. coalitus, and $D$. quinqueramus allows these Antarctic calcareous sediments to be positioned relative to the known biostratigraphic framework and give some comparison of this area with more northerly warm areas. However, the low numbers of these zone fossils in the samples analyzed and their rare occurrence in the sediments do not allow the recognition of unequivocal zonal boundaries.

In general, the sediments at this site appear autochthonous. Minor amounts of reworked material were seen in one sample (Sample 13-3, $143 \mathrm{~cm}$ ), which contains a few specimens of Cyclicargolithus floridanus and $D$. deflandrei.

\section{SITE 266}

Site 266 was drilled in the south flank of the Southeast Indian Ridge, about $800 \mathrm{~km}$ from the ridge crest. The sediments cored range from Recent to lower Miocene. They can be subdivided into three distinct units: (1) the upper, exclusively siliceous sediments; (2) the middle sediments containing predominantly siliceous microfossils, but also a small number of calcareous microfossils; and (3) the lower sediments containing some siliceous microfossils, but also containing significant amounts of calcareous microfossils.

\section{Upper Unit}

Upper siliceous unit (Samples 1-1, $60 \mathrm{~cm}$ to 9-2, 63 $\mathrm{cm}$ ): Stratigraphic ages or zones based on nannofossils cannot be assigned to this upper unit. Only one horizon contains sparse nannofossils (Sample 1-4, $90 \mathrm{~cm}$ ) (Tables 2A-D) and these were poorly preserved specimens of the placolith species Cyclococcolithus leptoporus and a small Gephyrocapsa species.

\section{Middle Unit}

Middle siliceous unit (Samples 9-3, $64 \mathrm{~cm}$ to 12-3, 90 $\mathrm{cm}$ ): In this unit poor preservation of the nannofossils makes species identification and hence accurate age assignment difficult. Abundance varies greatly within short distances between samples, but nannofossils are generally rare to few. Despite this low abundance, some diagnostic species are present which allow a stratigraphic subdivision of the section.

\section{Lower Pliocene (Samples 9-3, $64 \mathrm{~cm}$ to 9, CC)}

Siliceous microfossil stratigraphy indicates a lower Pliocene age for this interval. A lower Pliocene age is also suggested for these two samples by the presence of $D$. brouweri and $D$. pentaradiatus. Furthermore, the presence of occasional specimens of $C$. leptoporus $D$. pansus, $D$. variabilis, and $R$. pseudoumbilica is consistent with the lower Pliocene age. However, this same overlap of nannofossil species can also be found in upper Miocene sediments, and in the absence of the lower Pliocene/upper Miocene zone fossils Ceratolithus rugosus, C. tricorniculatus, D. quinqueramus the lower Pliocene/upper Miocene cannot be separated on the basis of nannofossils. By correlation with the siliceous microfossil stratigraphy, this part of the core is assigned a lower Pliocene age.

Upper Miocene (Samples 10-1, $60 \mathrm{~cm}$ to 12-3,90 cm)

As at Site 265 , Site 266 contains D. stellulus in the upper Miocene. In general, diagnostic upper Miocene 
TABLE 2A

Distribution of Nannofossils at Site 266

\begin{tabular}{|c|c|c|c|c|c|c|c|c|c|c|c|c|c|c|c|}
\hline $\begin{array}{c}\text { Sample } \\
\text { (Interval } \\
\text { in } \mathrm{cm} \text { ) }\end{array}$ & 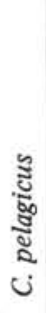 & 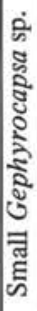 & 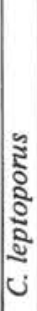 & 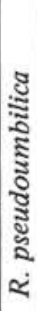 & 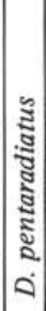 & 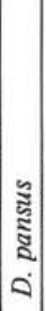 & 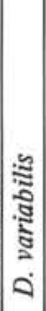 & $\left|\begin{array}{c} \\
\vdots \\
\vdots \\
\vdots \\
\vdots \\
\vdots \\
\vdots \\
\vdots \\
\vdots \\
\vdots\end{array}\right|$ & 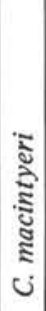 & 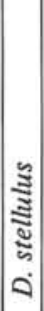 & 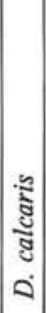 & 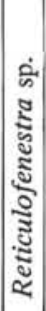 & $\begin{array}{c}3 \\
\vdots \\
\vdots \\
\vdots \\
\vdots \\
\vdots \\
\vdots\end{array}$ & 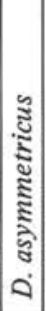 & \\
\hline $\begin{array}{c}1-1,60 \\
\text { to } \\
1-3,60\end{array}$ & \multicolumn{15}{|c|}{ Barren } \\
\hline $1-4,90$ & & + & + & & & & & & & & & & & & \\
\hline $\begin{array}{c}2-2,60 \\
\text { to } \\
9-2,63\end{array}$ & \multicolumn{15}{|c|}{ Barren } \\
\hline $9-3,64$ & + & & $\mathrm{R}$ & + & $\mathrm{R}$ & $\mathrm{R}$ & $\mathrm{R}$ & $\mathrm{X}$ & B & & & & & & \\
\hline $9-4,148$ & + & & B & + & $\mathrm{R}$ & & $\mathrm{X}$ & $\mathrm{R}$ & B & $\mathrm{F}$ & & & & & \\
\hline $10-1,60$ & + & & B & + & & & & & B & $\mathrm{F}$ & & $\mathrm{F}$ & & & \\
\hline $10-2,60$ & + & & B & + & & & $\mathrm{R}$ & & B & $\mathrm{F}$ & & $\mathrm{F}$ & & & \\
\hline $10-2,130$ & & & B & + & & & $\mathrm{R}$ & & B & $\mathrm{F}$ & & $\mathrm{F}$ & & & \\
\hline $10-3,40$ & & & $\mathrm{~B}$ & + & & & & & $\mathrm{B}$ & $\mathrm{F}$ & & $\mathrm{F}$ & & & \\
\hline $10-3,110$ & & & & + & & & & & & $\mathrm{F}$ & & $\mathrm{F}$ & & & \\
\hline $10-4,45$ & + & & & + & & & & & & $\mathrm{F}$ & & $\mathrm{F}$ & & & \\
\hline $10-5,40$ & & & & + & & & & & B & $\mathrm{F}$ & & $\mathrm{F}$ & & & \\
\hline $10-5,108$ & + & & & + & & & $\mathrm{F}$ & & & $\mathrm{F}$ & $\mathrm{X}$ & & & & \\
\hline $10-6,41$ & & & & + & & & $\mathrm{S}$ & & & $F$ & $\mathrm{X}$ & & & & \\
\hline $10-6,110$ & & & & + & & & $\mathrm{S}$ & & & & & & & & \\
\hline $11-1,40$ & + & & & + & & & $\mathrm{S}$ & & & $\mathrm{F}$ & $\mathrm{X}$ & & & & \\
\hline $11-1,110$ & + & & & + & & & & & & & & & & & \\
\hline $11-2,41$ & + & & & + & & & & & & & & & & & \\
\hline $11-2,111$ & & & & + & & & & & & & & & & & \\
\hline $11-3,40$ & & & & + & & & $\mathrm{S}$ & & B & $\mathrm{R}$ & & & & & \\
\hline $11-3,110$ & + & & & + & & & $\mathrm{S}$ & & & $\mathrm{R}$ & & & & $\mathrm{X}$ & \\
\hline $11-4,30$ & + & & & + & & & & & & $\mathrm{R}$ & & & $\mathrm{X}$ & & \\
\hline $\begin{array}{l}11-4,106 \\
11-5,41 \\
11-5,110 \\
11-6,30\end{array}$ & & & & & & & & arre & & & & & & & \\
\hline $12-1,110$ & + & & & + & & & & & & & & & & & \\
\hline $12-2,130$ & + & & & & & & $\mathrm{S}$ & & & $\mathrm{R}$ & & & & & \\
\hline $12-3,39$ & + & & & & & & $\mathrm{S}$ & & & & & & & & $\mathrm{R}$ \\
\hline
\end{tabular}

Note: See Table $1 \mathrm{~A}$ for explanation of symbols.

nannofossils are absent from this site, except for the presence of occasional specimens of $D$. calcaris in Samples 10-5, $108 \mathrm{~cm} ; 10-6,41 \mathrm{~cm}$; and $11-1,40 \mathrm{~cm}$. Sample 11-3, $110 \mathrm{~cm}$ contains a few specimens of $D$. asymmetricus, a species more commonly associated with lower Pliocene sediments but which has its lower range in the Miocene. Sample 11-4, $30 \mathrm{~cm}$ contains one good specimen of $D$. toralus. The remaining nannofossils present are generally long-ranging species such as $D$. variabilis and $R$. pseudoumbilica. The only other significant stratigraphical range is the lowermost occurrence of C. leptoporus (Sample 10-3, $40 \mathrm{~cm}$ ) and C. macintyeri (Sample 10-5, $40 \mathrm{~cm}$ ).

Several reworked species are present throughout this upper Miocene section: $D$. deflandrei $(10-2,60 \mathrm{~cm}), C$. miopelagicus $(10-2,150 \mathrm{~cm}$ to $10-5,108 \mathrm{~cm})$, C. floridanus $(10-3,110 \mathrm{~cm})$, and $R$. cf. hillae $(11-3,40 \mathrm{~cm})$.
There is an interval of core which is barren of nannofossils in the lower part of this section $(11-4,106 \mathrm{~cm}$ to $11-6,30 \mathrm{~cm}$ ). The upper Miocene age for this section based on nannofossil stratigraphy corresponds closely with that based on siliceous microfossils.

\section{Middle Miocene (Samples 12-1, $110 \mathrm{~cm}$ to $17-1,110 \mathrm{~cm}$ )}

Recognition of middle Miocene sediments and positioning of the middle/lower Miocene boundary is relatively well defined on nannofossil distribution. The middle Miocene zone fossil Discoaster exilis is present in Samples $13-2,41 \mathrm{~cm}$ to $13-6,115 \mathrm{~cm}$. The middle/lower Miocene boundary is marked by the lowest occurrence of Sphenolithus heteromorphus $(17-1,110 \mathrm{~cm})$, this species being present in Samples 16-1, $61 \mathrm{~cm}$ to 17-1, 110 $\mathrm{cm}$. This positioning of the boundary is further indicated by the close correlation with foraminifer distribution in this core, the extinction of the foram Catapsydrax dissimilis (early Miocene) being just below this level.

\section{Middle/Lower Miocene boundary}

This is the only site in which the middle/lower Miocene boundary was sampled in the sites drilled on Leg 28. However, although the middle Miocene species $S$. heteromorphus occurs at this site, the positioning of the boundary between the middle and lower Miocene is still arbitrary and complex. The complexity of position is still further magnified when correlation with siliceous microfossils is attempted.

When dealing with nannofossil stratigraphy, there is considerable difference of opinion as to where this boundary should be placed. Martini and Worsley (1970) position the boundary coincident with the lower boundary of the $S$. heteromorphus Zone, as does Bukry (1971). However, Berggren (1972) positions the middle/lower Miocene boundary within the $S$. heteromorphus Zone at 16 m.y. Hence, there is apparently two different positions at which this boundary can be positioned relative to the occurrence of $S$. heteromorphus at Site 266. However, the situation is further complicated at Site 266 by the inability to accurately position the lower boundary of the $S$. heteromorphus Zone. The lower boundary of the $S$. heteromorphus Zone was originally defined by Martini and Worsley as the position of the last occurrence of Helicopontosphaera ampliapetra (lower Miocene). However, H. ampliapetra does not occur in sediments at Site 266. Beneath the sediments containing $S$. heteromorphus there is a section of sediment which does not contain any species which fit into the known zonal schemes. Beneath this level is a section of sediment which contains the lower Miocene zone fossil $S$. belemnos. It may well be that the interval between the occurrences of $S$. heteromorphus and $S$. belemnos represents and is equivalent to the $H$. ampliapetra Zone of lower latitudes, but in the absence of the species itself, it is incorrect to make this assumption definitely.

Some further indication, however, of the correct positioning of this boundary is given by the youngest occurrence of $S$. dissimilis in Sample $18-2,40 \mathrm{~cm}$. This species 
TABLE 2B

Distribution of Nannofossils at Site 266

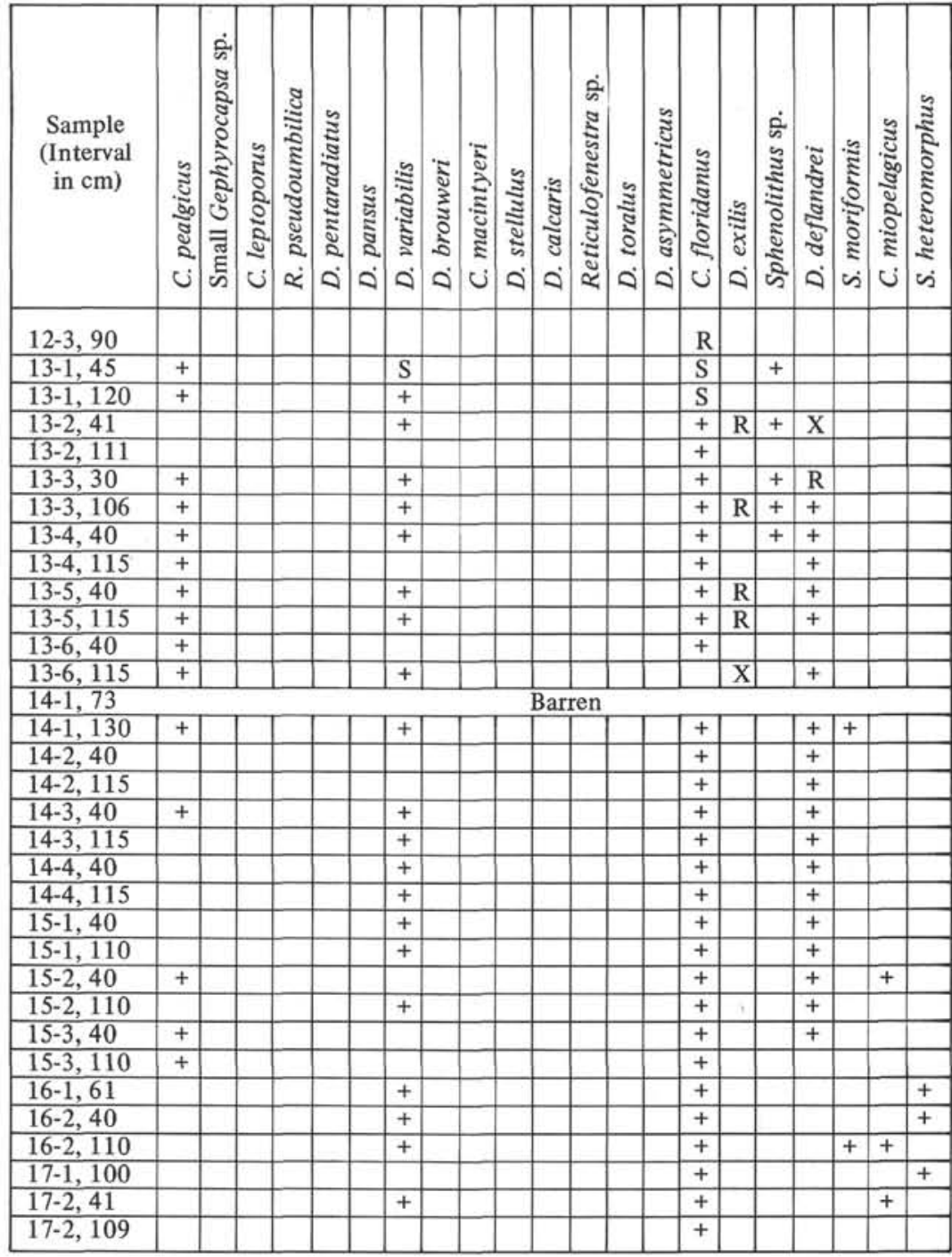

Note: See Table 1A for explanation of symbols.

described by Bukry and Percival (1971) has previously been recognized from lower Miocene sediments of the Pacific Ocean. This information taken in conjunction with the distribution of the lower Miocene foraminifera Catapsydrax dissimilis in Core 18 clearly indicates that Core 18 is lower Miocene. For these reasons, the middle/lower Miocene boundary is placed at the lowest occurrence (down the core) of $S$. heteromorphus (Sample $17-1,100 \mathrm{~cm})$.

It should be noted that this positioning of the boundary does not correlate with that based on siliceous microfossils, particularly that of silicoflagellates. However, this conflict in correlation has been discussed in full in the Introduction (this volume).

\section{Lower Miocene}

The uppermost lower Miocene nannofossil zone (NN4) cannot be positioned at this site as the zone fossil
H. ampliapetra is not present in the sediments. For reasons explained above, the age gap between the first occurrence of $S$. heteromorphus and last occurrence of $S$. belemnos may possibly be equated to this zone (Samples $17-2,40 \mathrm{~cm}$ to $19-1,40 \mathrm{~cm}$ ). The lower Miocene $S$. belemnos Zone (NN3) can be recognized at this site by the presence of the nominate zone fossil in Samples 19-1, $115 \mathrm{~cm}$ to $19-6,115 \mathrm{~cm}$. Beneath this zone accurate assignment of the sediments to fit previously described zonal schemes is impossible because of the absence of zone fossils, particularly the species Triquetorhabdulus carinatus and good specimens of $D$. druggi. Some specimens approximating to $D$. druggi were present in Samples 10-1, $70 \mathrm{~cm}, 20-2,40 \mathrm{~cm}, 20-4,40 \mathrm{~cm}$, and 21-1, $115 \mathrm{~cm}$, but the preservation of these discoasters is poor, and accurate identification is therefore doubtful.

Some age indication can be deduced from this section, however, by the presence of considerable numbers of $D$. trinidadensis (Sample 20-2, $40 \mathrm{~cm}$ to Sample 22-4, 115 
$\mathrm{cm}$ ) in conjunction with the persistent presence of numbers of $D$. deflandrei (Table 2). This overlap of species indicates that the lower section of the site is near to the Miocene/Oligocene boundary. Because of the absence of the zone fossil $T$. carinatus, whose range straddles this boundary, and the lower range of $D$. deflandrei and $D$. trinidadensis in the upper Oligocene, it is extremely difficult to know which side of the boundary these sediments should correctly be placed. However, the absence of the upper Oligocene species Dictyococcites abisecta indicates that this section is definitely early Miocene in age. The base of Site 266 is therefore assigned to the $D$. deflandrei Zone of Bukry (1971) with an absolute age determination of 21 m.y.

The presence of enormous quantities of C. miopelagicus in the lowest horizons at this site (Sample 22-240 to Sample 22-4-115) is probably an environmental effect and cannot be given any true stratigraphical significance.

\section{SITE 267}

Site 267 is located in the deep basin south of the Southeast Indian Ridge and about $600 \mathrm{~km}$ north of the Wilkes Land continental shelf. The sediments cored at this site range in age from Recent to lower Oligocene. As at the other sites, they can be subdivided into units: (1) upper siliceous section and (2) lower calcareous section.

\section{Upper Unit}

Upper siliceous section (Sample 1-1, $122 \mathrm{~cm}$ to Sample 4-1, $52 \mathrm{~cm}$ ): No nannofossils were present in this section.

\section{Lower Unit}

Lower calcareous section (Sample 4-1, $115 \mathrm{~cm}$ to Core 6): The contact between siliceous and calcareous sediments was not cored at this site. It cannot therefore be estimated whether the transition from the Miocene siliceous sediments in Core 3 to the calcareous Oligocene sediments in Core 4 is a gradual or abrupt change. It therefore remains unknown whether the Miocene sediments rest unconformably on the Oligocene sediments.

The lower calcareous section generally contains abundant, moderately well-preserved nannofossils.

\section{Upper Oligocene}

The nannofossil-bearing sediments at this site cannot be positioned relative to the zonal scheme proposed by Martini and Worsley (1970) or Bukry (1971) as they lack the diagnostic Oligocene species Sphenolithus ciperoensis, $S$. distensus, and $S$. predistensus. However, the species which are present, their abundance, range, and overlaps of range when compared with the Oligocene stratigraphic framework proposed by Roth et al. (1970) allows a stratigraphic subdivision for these sediments at Site 267. However, once again there are problems in arriving at a stratigraphic subdivision of these antarctic sediments as the previously described zoned sections are based on warm-water assemblages. Hence, in these high latitude assemblages many of the major diagnostic species described by Roth et al. must be ignored and in-
TABLE 2C

Distribution of Nannofossils at Site 266

\begin{tabular}{|c|c|c|c|c|c|c|c|c|c|c|c|c|}
\hline $\begin{array}{c}\text { Sample } \\
\text { (Interval } \\
\text { in } \mathrm{cm} \text { ) }\end{array}$ & 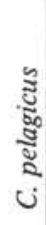 & 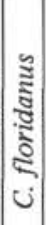 & 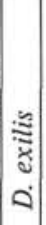 & 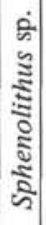 & 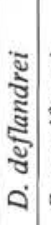 & 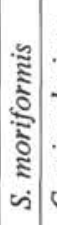 & 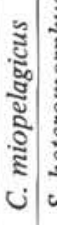 & 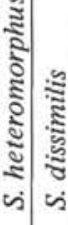 & 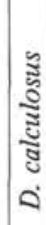 & 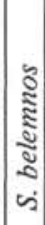 & 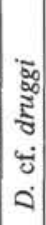 & 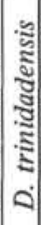 \\
\hline $17-3,40$ & & + & & & + & & & & & & & \\
\hline $17-3,110$ & & + & & & + & & & & & & & \\
\hline $17-4,40$ & + & + & & & + & & & & & & & \\
\hline $17-4,110$ & + & + & & & + & & + & & & & & \\
\hline $17-5,40$ & & + & & & + & & & & & & & \\
\hline $17-5,110$ & + & + & & & + & & & & & & & \\
\hline $18-1,102$ & & + & & & + & & + & & & & & \\
\hline $18-2,40$ & + & $\begin{array}{lll}+ & & \end{array}$ & & & + & & $\begin{array}{ll}+ \\
+\end{array}$ & + & & & & \\
\hline $18-2,110$ & + & + & & & + & & & + & & & & \\
\hline $18-3,53$ & + & + & & & + & & & + & & & & \\
\hline $18-4,130$ & + & + & & & + & & & & & & & \\
\hline $13-4,40$ & + & + & & & + & & + & & & & & \\
\hline $18-4,110$ & + & + & & & + & & + & + & & & & \\
\hline $18-5,40$ & + & + & & & + & & + & + & & & & \\
\hline $18-5,115$ & + & + & & & + & & + & + & & & & \\
\hline $19-1,40$ & + & + & & & + & & & & + & & & \\
\hline $19-1,115$ & + & + & & & + & & & & + & & & \\
\hline $19-2,40$ & + & + & & & + & & + & + & + & + & & \\
\hline $19-2,115$ & + & + & & & + & & + & + & & + & & \\
\hline $19-3,40$ & + & + & & & + & & + & + & & + & & \\
\hline $19-3,115$ & + & + & & & + & & & & & + & & \\
\hline $19-4,40$ & + & + & & & + & & & & & + & & \\
\hline $19-4,115$ & + & + & & & + & & + & + & & + & & \\
\hline $19-5,40$ & + & + & & & + & & + & + & & + & & \\
\hline $19-5,115$ & + & + & & & + & & + & + & & + & & \\
\hline $19-6,40$ & & + & & & + & & + & + & & + & & \\
\hline $19-6,115$ & & + & & & + & & + & + & & & & \\
\hline $20-1,70$ & + & + & & & + & & + & + & & & + & \\
\hline $20-1,130$ & + & + & & & + & & + & + & & & & \\
\hline $20-2,40$ & + & + & & & + & & + & + & & & + & + \\
\hline $20-2,115$ & + & + & & & + & & + & + & & & & + \\
\hline
\end{tabular}

Note: See Table 1A for explanation of symbols.

stead the overlap of ranges of the background placolith species must be compared with the assemblages at Site 267 . In this way reasonably reliable age determinations can be made for Site 267 calcareous sediments.

As at Site 266, the lack of the lower Miocene/upper Oligocene zone fossil $T$. carinatus makes it difficult to assess whether the uppermost sediments of Core 4 are lower Miocene or upper Oligocene in age. However, the common presence of $C$. altus, a particularly important and useful stratigraphic species for southern Pacific Oligocene sediments, gives clear indication that the sediments of Core 4 are Oligocene in age. This age is further indicated by the presence of $C$. floridanus and Dictyococcites scrippsae in Core 4. The presence of occasional specimens of $S$. cf. dissimilis in Samples 4-1, $111 \mathrm{~cm}$; 4-3, $122 \mathrm{~cm}$; and 4-4, $122 \mathrm{~cm}$ suggests that the uppermost sediments of Core 4 are uppermost Oligocene in age and this is further indicated by the continued presence of small numbers of $D$. deflandrei in Samples 4-1, $115 \mathrm{~cm}$ to $4-4,52 \mathrm{~cm}$.

The most useful indication for subdivision of the lower parts of this calcareous section is given by the 
TABLE 2D

Distribution of Nannofossils at Site 266

\begin{tabular}{|c|c|c|c|c|c|c|c|c|c|c|c|c|}
\hline $\begin{array}{l}\text { Sample } \\
\text { (Interval } \\
\text { in } \mathrm{cm} \text { ) }\end{array}$ & 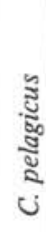 & 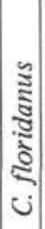 & 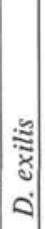 & 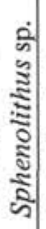 & 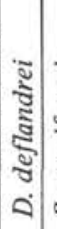 & 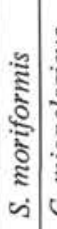 & 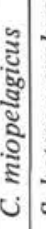 & 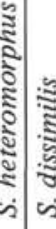 & 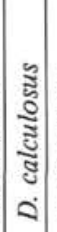 & 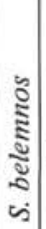 & 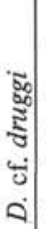 & 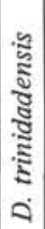 \\
\hline $20-3,43$ & + & + & & & + & & + & & & & & + \\
\hline $20-3,115$ & + & + & & & + & & + & & & & & + \\
\hline $20-4,40$ & + & + & & & + & & + & & & & + & + \\
\hline $20-4,115$ & + & + & & & + & & + & & & & & + \\
\hline $21-1,40$ & + & + & & & + & & + & & & & & + \\
\hline $21-1,115$ & + & + & & & + & & + & + & & & + & + \\
\hline $21-2,40$ & & + & & & + & & + & & & & & + \\
\hline $21-2,115$ & & + & & & + & & + & & & & & + \\
\hline $21-3,40$ & & + & & & + & & + & & & & & + \\
\hline $21-3,115$ & & + & & & + & & + & & & & & + \\
\hline $21-4,40$ & & + & & & + & & + & & & & & + \\
\hline $21-4,115$ & & + & & & + & & + & & & & & + \\
\hline $21-5,40$ & & + & & & + & & + & & & & & + \\
\hline $21-5,115$ & & + & & & + & & + & & & & & + \\
\hline $21-6,40$ & & + & & & + & & + & & & & & + \\
\hline $21-6,115$ & & + & & & + & & + & & & & & + \\
\hline $22-1,40$ & & + & & & + & & + & + & & & & + \\
\hline $22-1,115$ & & + & & & + & & + & & & & & + \\
\hline $22-2,40$ & & + & & & + & & $\mathrm{C}$ & & & & & + \\
\hline $22-2,115$ & & + & & & + & & $\mathrm{C}$ & & & & & + \\
\hline $22-3,40$ & & + & & & + & & $\mathrm{C}$ & & & & & + \\
\hline $22-3,115$ & & + & & & + & & C & + & & & & + \\
\hline $22-4,40$ & & + & & & + & & C & & & & & + \\
\hline $22-4,115$ & & + & & & + & & C & $\begin{array}{llll}+ & & 0\end{array}$ & & & & + \\
\hline
\end{tabular}

Note: See Table 1A for explanation of symbols.

overlap in the ranges of the two species, Dictyococcites abisectus and $D$. bisectus. This overlap gives a general indication of the position of the boundary between upper and mid Oligocene (Roth, 1970). Such an overlap occurs in the base of Core 4 at Site 267 and suggests that Core 4 is upper Oligocene and Core 5 is mid Oligocene in age.

It should be noted that although the Oligocene is often subdivided only into late and early stages (Berggren, 1972), the term mid Oligocene is used here, as the correlations and age determinations have been based on the zonation indicated by Roth (1970a, 1970b), which employs an upper, mid, and lower Oligocene subdivision of the section.

In the absence of the Oligocene zonal Sphenolith species, further refinement of the correct stratigraphic positioning of the calcareous sediments of Core 5 can be achieved by correlation with Roth et al. (1970). At the bottom of Core 5 there is no $R$. umbilica present and specimens of $D$. abisectus are extremely rare. This distribution positions the sediments within the $S$. predistensus Zone with a probable absolute age of 27-30 m.y. (Bukry, 1973) or 28-34 m.y. (Berggren, 1972).

Similar difficulties are encountered in attempting to position the lowermost calcareous sediment in contact with the basement basalt in Core 6. In the one sample analyzed from this core, $R$. umbilica is commonly present, along with rare specimens of $S$. moriformis, Chiastomolithus oamaruensis, $C$. altus, and $R$. hillae. Speci- mens of D. bisecta are also common and are accompanied by rare specimens of Ericsonia subdisticha. It is clear from the great increase in $R$. umbilica in the sample that Core 6 is stratigraphically below the $S$. predistensus Zone of Core 5. However, in the absence of the lower Oligocene zone fossil Helicopontosphaera reticulata and upper Eocene zone fossil Discoaster barbadiensis from these high-latitude sediments, the accurate positioning of the sample in the lower Oligocene or upper Eocene is difficult to assess. The presence of E. subdisticha in the sample would suggest that Core 6 is the lower Oligocene subzone of the $H$. reticulata Zone (Bukry, 1971) or the E. subdisticha Zone of Roth et al. (1970). However, for the assemblage to conform to these zones, there should be considerable numbers of $C$. formosa present. This species was not found in Core 6. Further assistance cannot be gained from correlation with the species ranges indicated by Roth et al. (1970) as S. pseudoradians (late Eocene subzone) was not identified in these southern sediments and the lower Oligocene $H$. reticulata Zone, subzonal fossils $R$. laevis and $C$. margaritae were not identified in this material.

On the presence of $E$. subdisticha in Core 6, therefore, the sediment/basalt contact at this site must be positioned in the lower Oligocene (E. subdisticha Subzone), which would give this contact an absolute age of 35-37 m.y. (Berggren, 1972) or 37-38 m.y. (Bukry, 1973). The absence of $C$. formosa from these sediments must therefore be attributed to an environmental effect.

No nannofossils were present in the sediments sampled at Hole 267A.

\section{HOLE 267B}

Hole 267B was situated a few kilometers south of Holes 267 and 267A. The greater portion of sediments cored consisted of an upper sequence of predominantly siliceous microfossil-bearing sediments (Core 1 to Core 9). Within this section a few sporadic thin horizons containing calcareous nannofossils occured, but the floras were very sparse and mainly consisted of very poorly preserved small Reticulofenestra species which afforded no age definition. In Core 10 there was a change to calcareous sediment which contained abundant nannofossils. This calcareous sequence was only short and rested on basalt basement.

When attempting an accurate age assignment for the calcareous nannofossil assemblages found at this site (Core 10), the same difficulties are encountered as at Site 267. The previously described upper Eocene zone fossils $S$. pseudoradians, D. barbadiensis, D. saipanensis (Martini and Worsley, 1970; Roth, 1970; Bukry, 1971) and the lower Oligocene zone fossil $\mathrm{H}$. reticulata are all missing from these Antarctic sediments. The only nannofossil species present in the sediment which has previously been designated as a zonal species is Isthmolithus recurvus (Martini and Worsley, 1970), a species typically found in sediment formed in cold water. Specimens of the genus Chiastomolithus are common in Core 10, but the greater number of such specimens are present as rims only, the specimens having lost their central cross. However, several well-preserved specimens of 
TABLE 3

Distribution of Nannofossils at Site 267

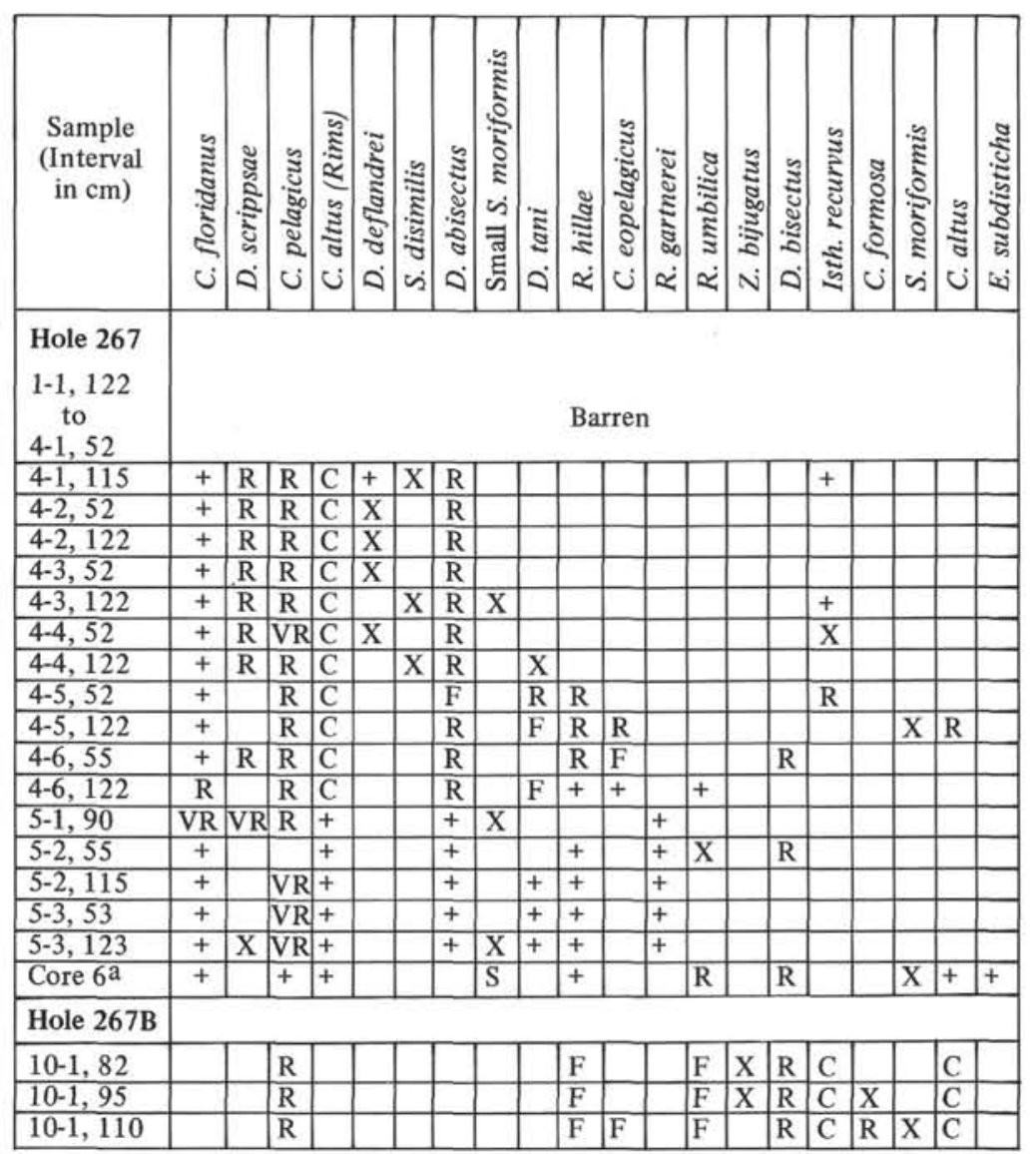

Note: See Table $1 \mathrm{~A}$ for explanation of symbols.

aSample from sediment/basalt contact.

C. altus are present in the assemblages and from comparison of size and rim features of these with the Chiastomolithus specimens minus the central cross, it would appear that most of these latter forms belong to $C$. altus. Only very rare specimens of $C$. oamaruensis are present. In the upper part of the short calcareous section (Sample 10-1, 82 cm) the assemblage contains no $C$. formosa, but in the lower sediments (Sample 10-1, $120 \mathrm{~cm}$ ) several specimens of $C$. formosa can be found. Similarly, in Sample 10-1, $110 \mathrm{~cm}$, just above basalt, this species is present in higher numbers. $R$. umbilica is present throughout Core 10 (Table 3 ), as is R. hillae.

From comparison with the species ranges and overlaps indicated by Roth et al. (1970) these sediments in Core 10 could be placed in the lower Oligocene, $H$. reticulata, or E. subdisticha zones because of the lack of $C$. formosa in these assemblages. However, the indications from the lower Oligocene sediments at Site 267 are that the lack of $C$. formosa is an environmental response and not an age one. Furthermore, the presence of substantial numbers of $I$. recurvus in the sediments of Hole 267B, but not in 267, clearly indicate that the sediments of Core 10, Hole 267B are stratigraphically lower than those of Core 6, Site 267, although the upper range of $I$. recurvus is in the Oligocene (Roth et al., 1970).

For this reason the sediments of Core 10, Hole 267B must be placed in the upper Eocene. This stratigraphic position, however, cannot be correlated with the $I$. recurvus Zone of Martini and Worsley or Roth et al. as the zone fossil for the uppermost Eocene (S. pseudoradians) has not been identified in Antarctic sediments. In the absence of such zone fossils, it is possible that these sediments could represent any position in the upper Eocene within the range limits of $I$. recurvus.

\section{SITE 268}

Site 268 was drilled on the lower continental rise just north of the Knox coast of Antarctica. Unlike the other sites (264 to 267), at Site 268 there was no lithologic change from an upper siliceous section to a lower calcareous section. In contrast to the other sites, Site 268 was generally unfossiliferous through its whole length.

Nannofossils were found occasionally in sporadic thin layers down the cores, but generally they were low in number and the species present were poorly preserved and often nondiagnostic of age. However, a few horizons contained nannofossils which give some indi- 
TABLE 4

Distribution of Nannofossils at Site 268

\begin{tabular}{|c|c|c|c|c|c|c|c|c|c|c|c|c|c|c|}
\hline $\begin{array}{l}\text { Sample } \\
\text { (Interval } \\
\text { in } \mathrm{cm} \text { ) }\end{array}$ & 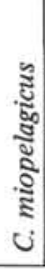 & 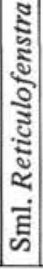 & 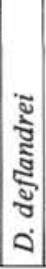 & 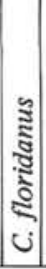 & 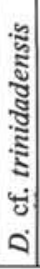 & 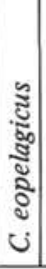 & 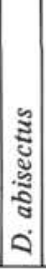 & 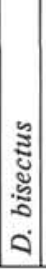 & 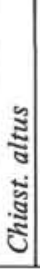 & 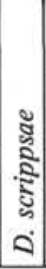 & 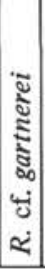 & 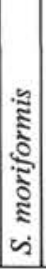 & 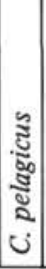 & 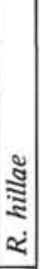 \\
\hline $\begin{array}{l}1-1-\text { top } \\
\text { to } \\
9, \mathrm{CC}\end{array}$ & \multicolumn{14}{|c|}{ Barren } \\
\hline $10-1$, top & $\mathrm{A}$ & C & $\mathrm{X}$ & & & & & & & & & & & \\
\hline $10-1,10$ & A & C & $\mathrm{X}$ & & & & & & & & & & & \\
\hline $\begin{array}{c}10-1,12 \\
\text { to } \\
13-1,22\end{array}$ & \multicolumn{14}{|c|}{ Barren } \\
\hline $13-1,23$ & & & $\mathrm{X}$ & $\mathrm{F}$ & $\mathrm{X}$ & C & $\mathrm{X}$ & & & & & & & \\
\hline $\begin{array}{c}13-1,25 \\
\text { to } \\
16, \mathrm{CC}\end{array}$ & \multicolumn{14}{|c|}{ Barren } \\
\hline $17-1$, top & & + & & + & & + & + & $\mathrm{X}$ & + & & & & & \\
\hline $\begin{array}{l}17-1,3 \\
\text { to } \\
17-2,129\end{array}$ & \multicolumn{14}{|c|}{ Barren } \\
\hline $17-2,130$ & & & & & & & & $\mathrm{X}$ & + & + & + & & + & \\
\hline $17-2,150$ & & & & + & & $\mathrm{R}$ & + & + & C & + & & & & \\
\hline $17-3,9$ & & + & & & & & & & + & & & $\mathrm{X}$ & & $\mathrm{X}$ \\
\hline
\end{tabular}

Note: See Table 1A for explanation of symbols.

cations of age (Table 4). Sample 10-1, $10 \mathrm{~cm}$ contained species such as $C$. miopelagicus and $D$. deflandrei, suggesting a mid to early Miocene age. A calcareous "spot" in Core 13, Section 1 contained D. deflandrei, C. floridanus, D. trinidadensis, C. eopelagicus, D. abisectus, and $S$. moriformis indicating an early Miocene age. Core 17 , Section 1 contained a thin horizon with a nannofossil assemblage containing $C$. floridanus, $C$. eopelagicus, $D$. abisectus, D. bisectus, and Chiastomolithus altus indicating an upper mid Oligocene age. Core 17, Section 2 contained two horizons which gave sparse nannofossil assemblages, containing specimens of $C$. floridanus, $C$. eopelagicus, D. abisectus, D. bisectus, considerable numbers of $C$. altus, and occasional specimens of $D$. scrippsae, $S$. moriformis, $R$. cf. gartneri, and $R$. hillae, indicating a mid Oligocene age. The lowest nannofossilbearing horizon was Sample 17-3, 9 which also contained a sparse assemblage with specimens of $D$. bisectus, $C$. altus, and $R$. hillae, suggesting a lower mid Oligocene. The sediments below this horizon (Cores 1820) were barren of all microfossils.

\section{SITE 269}

No nannofossils were seen at this site.

\section{SITE 270}

The sediments cored at Site 270, the first site drilled in the Ross Sea, contain little calcareous material. Only two thin calcareous horizons were found to contain nannofossil assemblages. Sample 18-2, $69 \mathrm{~cm}$ contained a few specimens of a small Reticulofenestra species and $C$. floridanus, suggesting a Miocene or Oligocene age. The
TABLE 5

Distribution of Nannofossils at Site $\mathbf{2 7 0}$

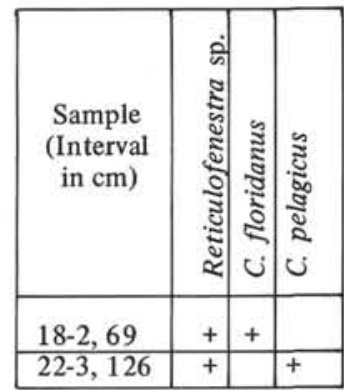

Note: See Table $1 \mathrm{~A}$ for explanation of symbols

second horizon, Sample 22-3, $120 \mathrm{~cm}$, contained occasional specimens of a small Reticulofenestra species and $C$. pelagicus, neither species giving any age indication (Table 5). Preservation of the few specimens present was generally very poor.

\section{SITE 274}

Nannofossils were present only in isolated horizons and burrows in a short section (Cores 21 to 28) at Site 274. Poor assemblages were present in Samples 21-1, 93; $21-3,70 ; 21-3,100 ; 27-4,104$. The best assemblages were in Samples 21-1, 93 and 21-3, 70 and these were dominated by $C$. altus suggesting an Oligocene age. Other species present in low numbers were $C$. pelagicus, D. scrippsae, and a small Reticulofenestra species (Table $6)$.

TABLE 6

Distribution of Nannofossils at Site 274

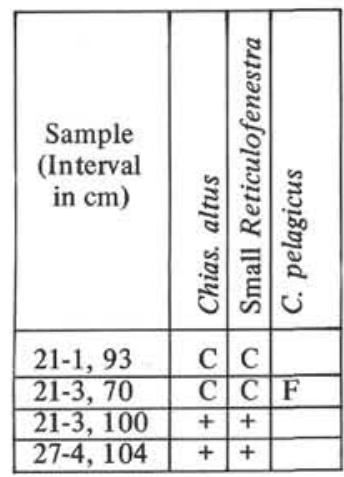

Note: See Table 1A for explanation of symbols

\section{REFERENCES}

Berggren, W.A., 1972. A Cenozoic time scale-some implications for regional geology and paleobiogeography. Lethaia v. 5, p. 195-215. 
Bukry, D. 1971. Cenozoic calcareous nannofossils from the Pacific Ocean: San Diego Soc. Nat. Hist., Trans., v. 16, p. 303-28.

1973. Coccolith stratigraphy, eastern Equatorial Pacific, Leg 16 Deep Sea Drilling Project. In van Andel, T.H., Heath, G.R., et al., Initial Reports of the Deep Sea Drilling Project, Volume 16: Washington (U.S. Government Printing Office), p. 653-711.

Bukry, D. and Percival, S.F., 1971. New Tertiary calcareous nannofossils: Tulane Stud. Geol. Paleontol., v. 8, p. 12346.
Martini, E., 1970. Standard Paleogene calcareous nannoplankton zonation: Nature, v. 226, p. 560-61.

Martini, E. and Worsley, T., 1970. Standard Neogene calcareous nannoplankton zonation: Nature, v. 225, p. 289-90.

Roth, P.H., 1970. Oligocene calcareous nannoplankton biostratigraphy: Eclog. Geol. Helv., v. 63, p. 799-881.

Roth, P.H., Baumann, P., and Bertolino, V., 1970. Late Eocene-Oligocene calcareous nannoplankton from Central and Northern Italy: In Farinacci, A. (Ed.), Plankt. Conf. Proc., 2nd. Rome (Tecnoscienza), p. 1069-1097. 